International Journal of

Emerging Multidisciplinary Research

\title{
Why Educational Reform Persists: With a View of Memetics
}

\author{
So Hee Yoon ${ }^{1}$, Bong Seok Jang ${ }^{2}$, Stanley F. Steiner ${ }^{3}$ \\ ${ }^{1}$ Undergraduate College of Basic \& General Education, Dongshin University, Naju, Jeonnam 58245, Korea \\ ${ }^{2}$ Department of Education, Mokpo National University, Muan, Jeonnam 58554, Korea \\ ${ }^{3}$ Department of Literacy, Language and Culture, Boise State University, Boise, ID 83702, U.S.A.
}

\begin{abstract}
Background/Objectives: This study aims to find an answer why "grammar of schooling" persists, even though different names of school reforms have been implemented. Methods/Statistical Analysis: The memetic theory is used as a good theoretical foundation because it provides a reasonable explanation to the situation regarding educational reforms. It helps people easily understand how ideas are transmitted and spread. A new idea may spread because it is good and useful. Memes are also selfish like genes because they have common characteristics to be passed on to the next generation and other areas. Findings: The concept of meme from the study of evolution was used to explain how the "grammar of schooling" can still survive, even though various school reforms have been introduced and vanished. Improvements/Applications: The most important factor to consider when implementing reform is acknowledging what the status quo is and how to keep making systemic change, small progress steadily, and achieving the ultimate goal of learning for all.
\end{abstract}

\section{Index Terms}

Educational reform, grammar of schooling, meme, memetics, selfish gene.

\footnotetext{
Corresponding author : Bong Seok Jang

bsjang@mokpo.ac.kr

- Manuscript received October 27, 2020.

- Revised November 19, 2020 ; Accepted December 1, 2020.

- Date of publication December 31, 2020.

(c) The Academic Society of Convergence Science Inc.

2546-1583 $\odot 2017$ IJEMR. Personal use is permitted, but republication/redistribution requires IJEMR permission.
} 


\section{INTRODUCTION}

Educational policies change over time to serve new needs according to our continuously transforming society. By the 1980s, school curricula and pedagogy were being shaped by global economic forces [1]. President George H. Bush and the governors met and talked about establishing clear national goals of student achievement, which would make American students more competitive. This educational proposal led to the No Child Left Behind Act (NCLB) signed by President George W. Bush [2]. In this law, it seems that American public schools became dominated by federal education policies and by the decisions of national political leaders. The NCLB Act also received much criticism by educators because of the limited body of research used to shape the law.

In addition, many teachers work to improve the education system from within. Some of them take part in various conferences and professional development programs. Others go to graduate school and gain new insights found in interesting research results, as well as educational theories related to how educators can help their students do better in school.

People have shared their opinions on educational changes and reforms, such as the above. It is often said that teachers' utopian ideas coupled with enthusiasm to help students who are struggling are stopped due to the resistance to change in administration [3]. In contrast, some people claim teachers are not eager to contribute to making changes in the school, even though policy makers and school-based researchers strongly say that every school can make significant progress in student's achievement [4]. In addition to the above, there are many other opinions. Tyack and Cuban (1995) said educational systems have barely changed from the "grammar of schooling. [5]" In their book, they describe, "little has changed in the ways that schools divide time and space, classify students and allocate grades and credits as evidence of learning" (p. 85). Besides, some people also say reforms, if ever fully achieved in education move at a glaciered pace. Others argue that there are too many changes in education. Tyack and Cuban (1995) described this contradiction on educational reform [5]:

While some lament that educational reform is an institutional Bermuda Triangle into which intrepid change agents sail, never to appear again, others argue that public education is too trendy, that entirely too many foolish notions circulate through the system at high velocity. Are schools too resistant to change or too faddish? Viewed over the course of history, they may seem to be both. Educators have often paid lip service to demands for reform to signify their alertness to the public will. But their symbolic responses often protected school people from basic challenges to their core practices. (p. 4)

It is also said that educational reforms have seldom replaced existing practice [6]. Most fail to produce predicted results. Many have become assimilated to previous patterns of schooling, even though they may have inserted alternative practices into the schools. Other reforms are not even welcomed by the staff and faculty at schools. So the question might be posed, "If the value of school reforms is not immediately self-evident and is considered like a comet which keeps coming around periodically, why do people pay so much attention to it and why do people keep thinking about it as a perfect solution for all the problems in society?" The solving of social problems through education does not seem to bring about change, as people have seen time and time again. Moreover, why does the "grammar of schooling" persist, even though different names of school reforms have been implemented? Isn't it faster just to carry out the new direct prescription to problems in society than expecting results from education? At this point, an emerging perspective of memetics may help us in analyzing these questions.

\section{What IS MEMETICS?}

Memetics is the theoretical and empirical science that studies the replication, spread, and evolution of memes within a culture [7]. A meme, defined as a unit of cultural transmission or imitation, was originally introduced in 1976 [8].

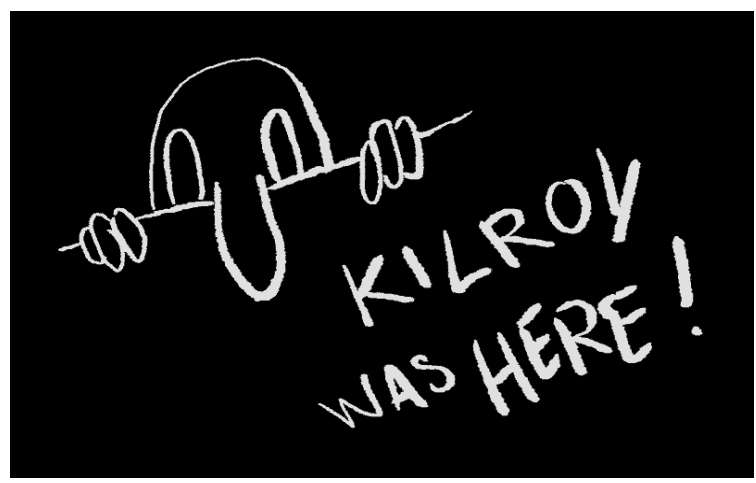

Fig. 1. The first widespread meme (Kilroy Was Here) [9].

One example is the computer language that has been transmitted and adopted worldwide. Zoom 
meetings did not exist five years ago. There are many other examples that transpire within a culture or subculture such as clothing fashions, religious practice, food diets, childhood games, et cetera. A meme is stored in the human brain [7]. Through meme analysis, Dawkins (1976) tried to deliver an idea of a unit of cultural transmission and replication [8]. This theoretical perspective enables people to see how everyday assumptions can be developed and spread.

Memes spread to other human beings through imitation. Memes have a life-cycle [10]. The ability of memes to pass through four stages determines fitness. The more fit the meme, the more likely it will make a lasting imprint on human culture. Blackmore (1999) uses the concepts of memefountains and meme-sinkholes to explain how memes are transmitted successfully or unsuccessfully [7]. Meme-fountains are people most often emulated: people of power, expertise, or authority.

Collections of meme complexes, or memeplexes, are used to explain the formation and the perpetuation of human organizations [7]. Religion is a common example used to illustrate this concept. Bjarneskans, Gronnevik and Sandberg (1996) explain [11]:

Religions represent some of the most powerful and elaborate meme complexes in existence today; they have evolved over millennia into countless variants and coevolved with cultures. Religions tend to consist of some basic core memes (in the case of Christianity the belief in God and salvation through Christ) surrounded by symbiotic doctrine memes (how salvation can be reached, ethical systems, the cosmology) and then an immense cloud of related memes (religious stories, doctrines, interpretations). These memes form a symbiotic whole; the core memes need symbiotic memes to provide hoods and baits, and the symbiotic memes reinforces each other and are given legitimacy by the core memes. (p. 16-17)

It is important to understand that successful memetical ideas replicate themselves often and are wide spread. The reason why they are particularly successful is that they are flexible, adaptable and can be turned into many different particular uses. On the other hand, there exist unsuccessful memes which rapidly disappear. A good deal of argument has taken place about the usefulness of memetics as a framework to explain how ideas are generated and circulated. Some applications to use the concept of memetics in education have begun to appear [12].
The reason why I choose memetics as an analytical framework is its focus on the mechanism of transmission of cultural patterns and its account of why these patterns can be propagated very quickly in social systems.

\section{Why SCHOOL REFORMS ARE NOT SUCCESSFUL MEMES}

With the concepts of meme, let us consider school reform and the "grammar of schooling" as types of phenomenon and cultural units. We will define the relationship between each of them and a type of meme. In short, the reason why school reforms cannot make big changes is that they have never been successful memes. To make policies successful and prosperous, it is very important to get consensus and agreement from people who work in the actual place, but often educators do not support politically motivated reforms. Educational reforms also do not seem to work out in practice as planned, so policymakers often blame educators. Policymakers believe their policies are all right, but policies do not take effect as intended and rarely take hold due to the perceived lack of competence of educators [13]. Administrative top down implementation in education has a long history of resistance from the folks in the trenches, teachers.

Practitioners, however, typically have a different interpretation. They think policymakers know very little about what schools should accomplish and just propose reforms that would never work as planned. Skeptical educators suspect that some reforms were put in place as a control mechanism and never were intended to work.

In addition, policies have often been planned without input from educators who work in the field. One good example of this is a merit pay system that was defeated by the teachers association in one western state in 2008. Educators were not willing to trade in their continuing contracts for the possibility of bonuses. One reason that educators give for the failure of merit pay systems is that when individual educators are rewarded for student achievement, the incentive for collaboration is killed. According to Rosenholtz (1985), "Pay teachers more, and they will teach better" is one of several political myths about education reform [14]. Schools are stronger when educators collaborate. The above mentioned merit pay plan attempted to side-step this problem as it rewarded whole schools for student achievement. Besides, applying the business model of rewarding workers for the quality of their work doesn't quite work in the public schools because the product of 
schools is students. There is little consensus on how to measure the complex notion of student achievement. Every child is complex in their needs and abilities.

Moreover, accountability systems which allow states to displace or remove teachers and administrators in low performing schools start to diminish the resistance of educators [14]. Teachers can easily feel pressure to improve test scores and only focus on the basics, a drill-and-kill methodology. This is at the expense of critical thinking skills, creativity and teaching to diversity. The quality of meme productiveness parallels this concept in the sense that the transmission of the meme must be effective.

According to Maehr and Maehr (1996), reforms to set standards are never welcomed in the school [15]. In addition, many reforms, ironically, have many potentially negative aspects in contrast to their original purposes.

Schools do need to be updated, reformed, improved, and transformed to meet not only the demands of a global economy, but most importantly, the needs of the students who will frame the future. Emphasizing standards is an all too ready, all too quick solution to a much more complex issue. Schools must stand for something. They must stand for learning. Schools must stand for the possibility that all students can learn, all students can improve, and all students must become independently motivated, lifelong learners. Defining and enforcing standards through the promiscuous use of standardized tests makes the school a sorting mechanism or a competitive game. That does not encourage student investment in learning as a lifelong enterprise. Sadly, it encourages the alienation of all too many who can only lose. And equally sad, it misdirects those with performance advantages to focus on attainments rather than on intellectual and personal growth. (p. 23)

The characteristics of reforms mentioned above state why they are unsuccessful memes. School reforms seem to pursue a unique goal, but eventually the common factor is to raise test scores. In this context, how can school reform be replicated and become successful? Conflict and internal disparity prohibit school reforms from spreading more widely and ultimately fail to make progress across the whole system.

\section{If So, What is A Successful MEME?}

What, then, has been the successful meme in education? Unfortunately, it is the "grammar of schooling". It has not changed much since the era of public education started, and it also seems to takehold into the future [16]. In the "grammar of schooling", the teacher is expected to be very authoritative and uses the very top-down approach; to monitor and control students, give assignment to students, and supervise the student's work [5]. Here comes the question. Why does the "grammar of schooling" persist, even though many people do think it is not an appropriate way of schooling? Routine practice is very difficult to change into different structures and rules. Teachers and administrators become complacent to routines. So the standard "grammar of schooling" has naturally become remarkably durable. In addition, rules in school are not easily questioned, because adults who were former students had familiar experiences there. Tyack and Cuban say that little change has been made in school.

The basic grammar of schooling, like the shape of classrooms, has remained remarkably stable for decades. Little has changed in the ways that schools divide time and space, classify students and allocate them to classrooms, splinter knowledge into "subjects," and award grades and "credits" as evidence of learning. (p. 85)

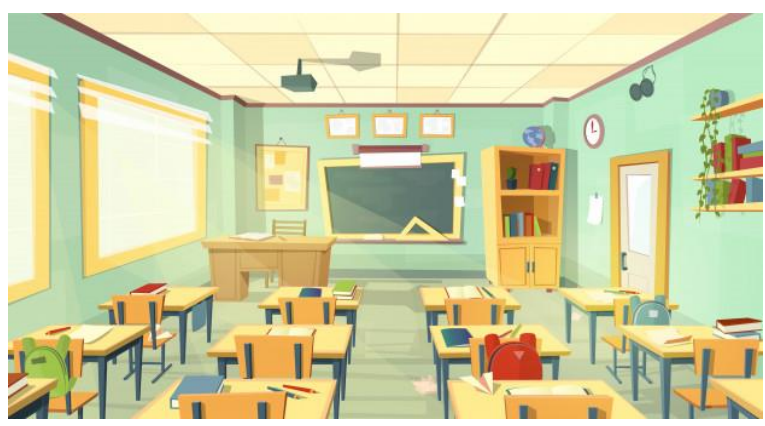

Fig. 2. Shape of classroom.

Considering these facts, it is possible that people may confirm why the "grammar of schooling" persists; it has enough reoccurring conditions to become a successful meme in contradiction to school reform. According to Bhatt (2005), teachers are comfortable with how they run their classrooms [17]. Teachers often say many school reforms are piled on their backs, a burden to their already full workload. They feel frustrated with new ideas taking time away 
from all their existing work. Korean educators are not immune to these reactionary thoughts and actions either. There may no group more than Koreans who show more interest in education and expectations to have their children academically succeed to attend the top colleges. So the issues regarding education including new educational reform policies are always important to Koreans. School reform policies in Korea tend to be changed many times based on who the minister of the Department of Education is at the moment [18]. There are much pressure and expectation for each new minister to develop innovative and sustainable reform policies. So the minister of education is usually regarded as the most difficult position in the Korean government. Due to these expectations the turnover of education ministers is also very high.

In this context, administrators and teachers are very skeptical to whatever new policies come out, because the policies are often developed and encouraged for implementation by university professors and politicians [19]. The same people rarely have experiences teaching students, working with parents, or as administrators in public education. Educators also think the ultimate goal of any school reform is about raising student achievement. With this goal, instead of paying attention to the new policy, to parents and to students, educators do not care about implementing the new policy and just teach students based on the standards to get higher test scores. Teachers tend to do the same work regardless of what kinds of educational reforms are implemented. They teach to the standards, check the test scores, and advise students which subject matter students need to spend more time on in the future to make adequate progress. So, nothing, in fact, has changed!

\section{Conclusion}

The memetic theory is used as a good theoretical foundation because it provides a reasonable explanation to this situation regarding educational reforms. It helps people easily understand how ideas are transmitted and spread. A new idea may spread because it is good and useful. Memes are also selfish like genes because they have common characteristics to be passed on to the next generation and other areas [8]. It is important to understand there might be a bridge to help ideas spread, but the usefulness of the idea itself is very important to be accepted and copied before transmission. People who are curious about how ideas are spread and transmitted need to think about ideas of meme, because ideas are attractive [20]. Teachers, especially, would have interest in meme theory, because they are considered as important mediators to spreading ideas in the educational fields. They have important roles.

Few examples under the concepts of successful memes are discussed. People have proposed many different kinds of plans for school reform, but the reforms did not work well primarily due to lack of involvement by the stakeholders, teachers. Instead, the "grammar of schooling" continues its stronghold against education reform due to its familiarity to people and ease of transmission.

The most important factor to consider when implementing reform is acknowledging what the status quo is and how to keep making systemic change, small progress steadily, and achieving the ultimate goal of learning for all. Looking at the current situation carefully is also very important. People have been trying to find solutions to the problems in society through education, but educational reforms fail to achieve planned goals. Reforms, sometimes, are not even welcomed. Reforms which are not rooted in reality cannot be successful. If people want to make reform come true, they may want to make sure who is going to be in position to implement and struggle to achieve a successful meme. People may not want the "grammar of schooling" to become the successful meme, but it has been true to course for decades. Changing something is not easy, because there are always sacrifices to be made and conflicts with the status quo. There has to be a shared willingness to move forward. If people are not really systemic about it, no change will take place.

\section{REFERENCES}

[1] Sheldon, K.M., \& Biddle, B.J. (1998). Standards, Accountability, and School Reform: Perils and Pitfalls. Teachers College Record, 100(1), 164-180.

[2] Birk, L. (2003). Spotlight on High-Stakes Testing. Cambridge, MA: Harvard Education Press.

[3] Christensen, L., \& Karp, S. (2003). Rethinking school reform: Views from the classroom. Milwaukee, WI: Rethinking Schools.

[4] Thrupp, M., Mansell, H., Hawksworth, L., \& Harold, B. D. (2003). Schools Can Make a Difference' - But do Teachers, Heads and Governors Really Agree? Oxford Review of Education, 29(4), 471-484.

[5] Tyack, D. \& Cuban, L. (1995). Tinkering toward utopia: A century of public school reform. Cambridge, MA: Harvard University Press.

[6] Angus, D. L. \& Mirel, J. E. (1999). The Failed Promise of the American High School, 1890-1995. New York: Teachers College Press

[7] Blackmore, S. (1999). The meme machine. New York: Oxford University Press.

[8] Dawkins, R. (1976). The selfish gene. New York: Oxford University Press

[9] Gardner, M. (2000). "Kilroy Was Here". Los Angeles Times. Marth 5th , 2000 
[10] Aunger, R. (2002). The electric meme: a new theory of how we think. New York: Free Press.

[11] Bjarneskans, H., Grønnevik, B., \& Sandberg, A. (2020). The Lifecycle of Memes. Retrieved from https://www.aleph.se/Trans/Cultural/Memetics/memecycle.h tml.

[12] Yoon, S. \& Woodruff, E. (2003, April). Rethinking teaching and learning about scientific and technological issues: exploring the development of memes in a complex system. Paper presented at the annual meeting of the American Educational Research Association, Chicago, IL.

[13] Spring, J. (2005). Conflict of Interests: the politics of American Education (5th ed.). Boston: McGraw-Hill.

[14] Rosenholtz, S. (1985). Political myths about education reform: Lessons from research on teaching. Phi Delta Kappan, 66(5), 349-355.

[15] Amrein, A.L., \& Berliner, D.C. (2002). An Analysis of Some Unintended and Negative Consequences of HighStakes Testing. Tempe, AZ: Educational Policy Studies Laboratory, Arizona State University.

[16] Maehr, M. L. \& Maehr, J. M. (1996). "Schools aren't as good as they used to be; they never were." Educational Researcher, 25(8), 21-24.

[17] Hill, P. T. \& Harvey, J. (2004). A Fresh Assessment: Why Reform Initiatives Fail? In Hill, P. T. \& Harvey, J. (Ed.) Making School Reform Work: New Partnerships for Real Change. (pp. 1-7). Washington, D.C.: Brookings Institution Press.

[18] Bhatt, S. (2005, January 03). Schools struggle to reduce high teacher turnover. The Seattle Times.

[19] Kim, S. (1999). Educational sociology. Seoul: Kyoyook Guahaksa.

[20] Jeong, W. \& Park, S. (1999). Educational problems in Korea. Seoul: Kyoyook Guahaksa. 